\author{
Case Study \\ www.ijrap.net (ISSN:2229-3566)
}

\section{AYURVEDIC MANAGEMENT OF SPASTIC CEREBRAL PALSY: A CASE STUDY} \\ Shailaja $\mathrm{U}^{1 *}$, Mangala Jyothsna $\mathrm{G} \mathrm{P}^{2}$ \\ ${ }^{1}$ Professor and Head, Department of Kaumarabhritya, Sri Dharmasthala Manjunatheshwara College of Ayurveda and \\ Hospital, Hassan, Karnataka, India \\ ${ }^{2}$ Post Graduate Scholar, Department of Kaumarabhritya, Sri Dharmasthala Manjunatheshwara College of Ayurveda and \\ Hospital, Hassan, Karnataka, India
}

Received on: 16/10/19Accepted on: 11/02/20

\author{
*Corresponding author \\ E-mail: rao.shaila@gmail.com
}

DOI: $10.7897 / 2277-4343.110219$

\begin{abstract}
Cerebral palsy is a non- progressive Neuromotor disorder of cerebral origin and is the leading cause of childhood disability. In India incidence is around 3/1000 live birth out of which $77.4 \%$ are identified to be suffering with spastic type of cerebral palsy. Spasticity is the velocity dependent increase in the tonic stretch reflexes with exaggerated tendon jerks. In Ayurveda CEREBRAL PALSY may be considered as Shiro Marmabhighata Vata Vyadhi (diseases caused due to injury to head). Though cerebral palsy cannot be cured completely the quality of life can be improved and dependency can be minimized with appropriate treatment. This case study focuses on the management of subject of spastic cerebral palsy with the administration of certain Ayurvedic internal and external treatment modalities. The subject was selected from inpatient department of Kaumarabhritya of SDM College of Ayurveda and Hospital, Hassan. Considering Vata, Kapha as the main Doshas involved, the subject had undergone Snehana, Swedana, Rukshana, Basti, Upanaha procedures in 12 sittings of intervention. The outcome was assessed using different parameters such as muscle power, tone, range of movement and posture. The subject showed considerable in reduction in spasticity and improvements in activities of daily living.
\end{abstract}

Keywords: Spastic Cerebral Palsy, Non-Progressive, Neuromotor Disorder, Vatavyadhi, Muscle Power.

\section{INTRODUCTION}

Cerebral palsy (CP) describes a group of permanent disorders of the development of movement and posture, causing activity limitation, that are attributed to non-progressive disturbances that occurred in the developing fetal or infant brain. The motor disorder of cerebral palsy are often accompanied by disturbances of sensation, perception, cognition, communication and behavior: by epilepsy and by secondary musculoskeletal problems. ${ }^{1}$ The incidence of cerebral palsy in India is 3/1000 live births among which $77.4 \%$ of the children are identified to be suffering with Spastic type of cerebral palsy. ${ }^{2}$ Spasticity is a motor disorder characterized by (i) exaggerated tendon jerks (hyper reflexia) and (ii) increased muscle response to applied stretch, positively correlated with the lengthening rate (velocity-dependent hypertonia). ${ }^{3}$

Cerebral Palsy cannot be correlated with any single condition mentioned in Ayurveda, as it is a multifactorial disease. However, considering the classification and the respective features of the types, Cerebral Palsy can be considered as Janma Bala Pravritta Vyadhi (congenital disorder). It can also be caused due to Doshas (bodily humors). It can be considered as Shiro Marmabhighata Vata Vyadhi (diseases caused due to injury to head). Where Marmaghata occurs due to various causes which are Garbhapurvaka (before conception), Prasava Purvaka (before delivery), Prasavakaleena (during delivery), Prasavottara (After delivery). ${ }^{4}$ The therapeutic management is done considering that it is Vata Kapha Pradhana, where Snehana, Swedana with Alternate Rukshana and Basti are the main line of treatment. This case study focuses on the management of subject of spastic cerebral palsy with the administration of certain Ayurvedic internal and external treatment modalities. The subject was selected from inpatient department of Kaumarabhritya of SDM College of Ayurveda and Hospital, Hassan. The subject had undergone treatment in 12 sittings of intervention. The outcome was assessed using different parameters such as muscle power, tone, range of movement and posture. The study is carried out as per International conference of Harmonization-Good Clinical Practices Guidelines (ICH-G Cerebral Palsy) or as per Declaration of Helsinki guidelines.

\section{Patient information}

Age - 1.6 years

Gender - Male

Socioeconomic status - Upper Middleclass (Kuppuswamy Scale $)^{5}$

Chief Complaints - C/o inability to sit, stand, walk with or without support, delayed speech since appropriate age.

History of Present Illness - The child was born out of nonconsanguineous marriage at $9^{\text {th }}$ month of gestation by forceps assisted vaginal delivery, baby did not cry immediately after birth having the birth weight of 3000 grams, h/o NICU stay for 11 days, and there is history of neonatal seizures during this period. After 11 days baby was discharged, and feeding was initiated. By 5-6 months parent noticed delay in development but it was neglected. Then the attainment of neck holding, sitting with support and crawling was delayed and was achieved after 1 year. For which they took consultation at an allopathic hospital was advised to undergo physiotherapy. Later at the age of 1 year 6 months they approached our hospital for further management. 


\section{Developmental history}

Table 1: Developmental milestones of the child

\begin{tabular}{|c|c|c|c|}
\hline Domains & Milestone & Attained at & Normal \\
\hline \multirow{4}{*}{ Gross motor } & Neck holding & 9 months & 3 months \\
\cline { 2 - 4 } & Sitting with support & 1.2 years & 6 months \\
\cline { 2 - 4 } & Rest & not attained & - \\
\hline \multirow{4}{*}{ Fine motor } & Bidextrous grasp & 8 to 9 months & 4 months \\
\cline { 2 - 4 } & Unidextrous grasp & 1 year & 6 months \\
\cline { 2 - 4 } & Reaches for object & 1.5 year & 6 months \\
\cline { 2 - 4 } & Rest & Not attained & - \\
\hline \multirow{4}{*}{ Language } & Turns head to sound & $6-7$ months & 1 month \\
\cline { 2 - 4 } & Cooing & 1.2 years & 3 months \\
\cline { 2 - 4 } & Rest & Not attained & - \\
\hline \multirow{2}{*}{$\begin{array}{c}\text { Personal and } \\
\text { social }\end{array}$} & Social smile & 9 months & 2 months \\
\cline { 2 - 4 } & Recognizes mother & 1 year & 3 months \\
\hline
\end{tabular}

\section{Clinical findings}

Anthropometry

Table 2: Anthropometry of the child at the time of admission

\begin{tabular}{|c|c|}
\hline HC & $45 \mathrm{~cm}$ \\
\hline CC & $49 \mathrm{~cm}$ \\
\hline MAC & $15 \mathrm{~cm}$ \\
\hline Length & $85 \mathrm{~cm}$ \\
\hline Weight & $9 \mathrm{~kg}$ \\
\hline
\end{tabular}

\section{Central nervous system examination}

- Higher mental functions

Conscious

Orientation to person and place - intact

Memory - immediate, Remote - intact

Speech - only monosyllables attained
- Cranial nerves

Occulomotor, Abducent, Trochlear - Convergent strabismus +; Rest - NAD

- Motor system

- Tone - Hypertonic - on B/L Lower limbs

- Power

Table 3: Muscle power of Upper limb and Lower limb

\begin{tabular}{|c|c|c|c|}
\hline \multicolumn{2}{|c|}{ Right } & \multicolumn{2}{c|}{ Left } \\
\hline UL & $4 / 5$ & UL & $4 / 5$ \\
\hline LL & $3 / 5$ & LL & $3 / 5$ \\
\hline
\end{tabular}

- DTR - exaggerated in B/L lower limbs

- Modified Ashworth Spasticity scale ${ }^{6}$ - Grade 3 at B/L knee and ankle

- Gait- Scissoring
Diagnosis

- Spastic diplegic cerebral palsy

- Shiromarmabhighatajavatavyadhi

Therapeutic intervention

Table 4: Treatment adopted in all the twelve sittings

\begin{tabular}{|l|l|}
\hline Sitting & Treatment \\
\hline First $-10 / 2 / 18-19 / 2 / 18$ & Externally - \\
Second $-19 / 3 / 18-3 / 4 / 18$ & - Udwarthana + Nadisweda \\
Third $-30 / 4 / 18-9 / 5 / 18$ & - Sarvanga abhyanga with prasarinitaila + parisheka with dashamulakashaya and Shashtikashali Pinda Sweda \\
Fourth $-7 / 7 / 18-25 / 7 / 18$ & in alternate sitting \\
Fifth $-25 / 8 / 18-10 / 9 / 18$ & - Udwarthana and abhyanga are done with 2 days alternate \\
Sixth $-20 / 10 / 18-1 / 11 / 18$ & - Shirodhara with dashamulakashaya for the first 2 sitting and Ksheerabalataila from the $3^{\text {rd }}$ to $8^{\text {th }}$ sitting \\
Seventh $10 / 12 / 18-19 / 12 / 18$ & - Shirothalam with Shankhapushpi + Vacha + Jatamamsi + Brahmi taila \\
Eighth $-21 / 1 / 19-31 / 1 / 19$ & - Matrabasti with Prasarinitaila -15 ml \\
Ninth $-11 / 3 / 19-25 / 3 / 19$ & - Yogabasti with Mustadi Yapanabasti - was planned in $3^{\text {rd }}, 5^{\text {th }}, 12^{\text {th }}$ sitting. \\
Tenth $-8 / 4 / 19-22 / 4 / 19$ & - Upanaha with Kola kulattadichurna + bala + Ashwagandha + rasna + Godhuma \\
Eleventh $-4 / 5 / 19-18 / 5 / 19$ & - Prishtapichu with prasarinitaila \\
Twelfth $-24 / 6 / 19-1 / 7 / 19$ & - Pratimarshanasya with Anu taila $2^{0} / 2^{0}$ drops \\
& - Pradhamananasya with vakshuddhikarachoorna (evening) \\
& - Asyapratisarana with vakshuddhikarachurna with honey BD \\
& Internally - \\
& - Kumarabharana rasa 1-0-0 with honey B/F \\
& - Ashwagandha leha $1-0-1$ tsp with milk B/F \\
\end{tabular}




\section{Follow up and outcome}

After the first sitting child started making sounds and showing joy to play with parents, reduction in the tightness in the knee joints, child started to crawl back and forth. After the second sitting of treatment the child started to look at mother while speaking and used to responds to her and started to sit without support. During third sitting of treatment he started to wave hands, sits without support for 30 minutes, tries to bear weight completely on floor. In the fourth sitting tries to stand with physical assistance, tries to speak ma, ba- monosyllables. After the fifth and sixth sitting started to understand the commands, tries to walk holding on to support, started to speak bisyllables, holds the object with immature pincer grasp. After seventh and eighth sitting understands every command, imitates what the mother teaches him, but the words are not clear, tries to climb stairs with support. After ninth, tenth, eleventh sitting the words have become clearer, understands everything what mother tells him and acts accordingly, will appropriately answer the questions asked, tries to scribble.

\section{DISCUSSION}

Udwarthana along with Abhyanga is followed in alternate manner, as per concept of Vyatyasachikitsa when both vata and kapha are involved the treatment followed should not aggravate either vata or kapha ${ }^{7}$, since both are having the opposite qualities except Sheethaguna (cold in potency) the udwartana will help in reduction of kapha ${ }^{8}$ and Abhyanga will help in reduction of vata. ${ }^{9}$ For abhyanga prasarinitaila is used - the indication of which says that it is best vatakapha hara, also will relieve Stambha (Stiffness) in various parts of the body..$^{10}$ As a part of Swedana Shashtika Shalipinda Sweda, Parisheka and Upanaha was opted. Shashtikashali pinda sweda, provides Brihmana, Dhatu Poshana (provides nourishment to body organs) and it's a prime procedure in mitigating Vata. ${ }^{11}$ Parisheka is a form of Drava sweda, here Dashamulakashaya was used which possess tridosha hara, Ushnaveerya, Katuvipaka, Tikta - Kashaya rasa and Laghu Ruksha Guna which relieves stambhana (Stiffness). ${ }^{12}$ Upanaha will reduce the stambha (stiffness) and acts as Vata Kapha hara which is the main feature in Spastic type of cerebral palsy. ${ }^{13,14}$ Shirodhara is a procedure which produces a constant pressure and vibration over brain which is enhanced by the hollow sinuses in the frontal bone. Probably if a prolonged pressure is applied on the nerve, the impulse conduction is interrupted and the part of the body relaxes ${ }^{15}$. Shirothalam is a procedure where medicaments are mixed with taila and applied over the region of anterior fontanalae, since the drugs selected are Medhya (improves cognitive functions) in nature along with Jatamamsi it helps in improving the functions of Uttamanga (brain) of the child. ${ }^{16}$ Basti is considered as Ardhachikitsa. ${ }^{17}$ and since medicaments can directly reach the blood circulation as rectum has rich blood supply, the substances can be directly absorbed into portal circulation. ${ }^{18}$ And it is indicated to be used in very young and very old age also. ${ }^{19}$ As the child's age was very young Shodhana Basti was planned in alternate sittings. Nasya was planned as the shiras is the uttamanga involved and the nasal cavity is highly vascularized therefore helps in avoidance of liver first pass effect, rapid absorption and higher bioavailability. ${ }^{20}$ The drugs selected also are capable of passing through the Sukshmasrotas (minute channels of the body), Asyapratisarana is a procedure where the medicaments are smeared all over the oral cavity along with honey, here the drugs get directly absorbed through the oral mucosa and Systemic exposure of drugs after oral mucosal administration is often expected to be a route of administration with a fast onset of action. ${ }^{21}$ So it may stimulate brain faster. Kumarabharana rasa possess drugs which have antioxidant property, antimicrobial property, anti-inflammatory, antioxidant, immune modulatory, antibacterial, antipyretic, scraping, digestive stimulant, carminative, nourishing and rejuvenation effects. ${ }^{22}$ Thereby maintaining the immunity of the child and minimizing the repeated infections. Ashwagandha Leha is having the properties of Balya (strengthening), Rasayana (rejuvenation effect). It provides nutrition to body and mind with adapto-immuno-neuro-endocrine-modulator properties. ${ }^{23}$ Baladi Yoga is formulated by including certain Vatahara drugs along with consideration of properties such as Rasayana (rejuvenation effect), Medhya (improves cognitive functions), Brumhana (nourishes body tissues), which are necessary to improve the ability in children of cerebral palsy. ${ }^{24}$

\section{CONCLUSION}

The treatment protocol followed here aims at reducing spasticity and improving the higher mental functions. The subject showed considerable improvement in gross motor functions, power and reduction of spasticity, scissoring and certain personal and social and language milestones. Though cerebral palsy cannot be cured completely the quality of life can be improved and dependency can be minimized with appropriate treatment.

\section{ACKNOWLEDGEMENT}

Authors offer thanks to the Chief Medical Officer, Medical Superintendent and all staffs of Kaumarabhritya Department of SDM college of Ayurveda and Hospital, Hassan, Karnataka, India and the parents of the subject who has actively participated in this study.

\section{REFERENCES}

1. Rosenbaum P, Paneth N, Leviton A, Goldstein M and Bax M. A report: The definition and classification of cerebral palsy April 2006 [Cited on 12 $2^{\text {th }}$ October 2019]. Developmental Medicine and Child Neurology. Blackwell Publishing Ltd. https://doi.org/10.1111/j.1469-8749.2007.tb12610.x; 2007.

2. https://www.cdc.gov/ncbddd/Cerebral palsy /data.html. [Cited on $23^{\text {rd }}$ January 2018]

3. Crenna, P. Spasticity and spastic gait in children with cerebral palsy. [Cited on $12^{\text {th }}$ October 19]. Neuroscience and Biobehavioral Reviews 1998; 22(4): 571-578. https://doi.org/10.1016/S0149-7634(97)00046-8

4. Shailaja U, Rao PN, Debnath P and Adhikari A. Exploratory study on the ayurvedic therapeutic management of cerebral palsy in children at a tertiary care hospital of Karnataka, India. [Cited On 12 ${ }^{\text {th }}$ October 2019]. Journal of Traditional and Complementary Medicine 2014; 4(1): 49-55. https://doi.org/10.4103/2225-4110.124345

5. Saleem SK M. Modified Kuppuswamy Scale Updated for Year. [Cited on $12^{\text {th }}$ October 2019]. Paripex- Indian Journal of Research 2018; 7(3): 436-6. Retrieved from https://www.researchgate.net/publication/323846030

6. Mutlu A, Livanelioglu A and Gunel MK. Reliability of Ashworth and Modified Ashworth Scales in children with spastic cerebral palsy. [Cited on $12^{\text {th }}$ October 2019]. BMC Musculoskeletal Disorders, 9; 2008. https://doi.org/10.1186/1471-2474-9-44

7. Shulka V, Tripathi RD ed, Charaka Samhita (ISBN: 978-817084-509-1) of Agnivesha, (Hindi). Vatavyadhichikitsa 28/219. Vol-2. Reprint. Chaukhambha Sanskrit Pratishthan, Delhi; 2013. p. 720.

8. Paradakara HS ed, Astangahrdaya (ISBN: 978-93-80326-764) of Vagbhata, (Sans), Dinacharyadhyaya 2/15, Chaukhambha Surabharati Prakashan, Reprint, Varanasi; 2016. p. 28. 
9. Paradakara HS ed, Astangahrdaya (ISBN: 978-93-80326-764) of Vagbhata, (Sans), Sutra. Dinacharyadhyaya. 2/8. Chaukhambha Surabharati Prakashan, Reprint. Varanasi; 2016. p. 26.

10. The Ayurvedic Pharmacopoeia of India (ISBN: 81-9011514-6), (Eng). Taila Prakarana 8/32. Vol $-1,2^{\text {nd }}$ ed. The controller of publications civil lines. Delhi; 2003. p. 411.

11. Shailaja U, Rao P, Girish K and Arun Raj G. Clinical study on the efficacy of Rajayapana Basti and Baladi Yoga in motor disabilities of cerebral palsy in children. [Cited on $12^{\text {th }}$ October 2019]. AYU (An International Quarterly Journal of Research in Ayurveda) 2014; 35(3): 294. https://doi.org/10.4103/0974-8520.153748

12. Arun Raj GR et al. Effectiveness of Ayurveda treatment modalities in the management of spasticity in children with cerebral palsy at a tertiary care teaching hospital of southern India. [Cited on $12^{\text {th }}$ October 2019]. Int. J. Res. Ayurveda Pharm 2018; Vol 9(2): 96-100. http://dx.doi.org/10.7897/2277-4343.09242

13. Sharma AR. ed, Sushruta Samhita (ISBN: 978-93-82443-520) of Maharsi Sushruta, Chikitsa, Swedavacaraniyadhaya, 32/14.2013. Reprint. Chaukhamba Surbharati Prakashan. Varanasi 2018. p. 419.

14. Sharma AR. ed, Sushruta Samhita (ISBN: 978-93-82443-520) of Maharsi Sushruta. Chikitsa. Vatavyadhichikitsa 4/16., Reprint. Chaukhamba Surbharati Prakashan. Varanasi; 2013. p. 206.

15. Kajaria D. Tripathi JS, Tiwari SK. An appraisal of the mechanism of action of shirodhara. [Cited on $12^{\text {th }}$ October 2019]. Annals Ayurvedic Med 2013; Vol 2(3): 114-117.

16. Shripathi Adiga, Ramya S Adiga. The concept of Thailam in Ayurveda: an analytical approach. [Cited on $12^{\text {th }}$ October 2019]. J of Ayurveda and Hol Med (JAHM) 2017; 5(4): 91100.

17. Shulka V, Tripathi RD ed, Charaka Samhita (ISBN: 978-817084-509-1) of Agnivesha (Hindi). Vol-2. Reprint. Siddhi. Kalpanasiddhi 1/40. Chaukhambha Sanskrit Pratishthan. Delhi 2013. p. 883.
18. Shulka GD. Pandey S, Thakar AB. Pharmacodynamic understanding of Basti: A contemporary approach. 2012 [Cited on $12^{\text {th }}$ October 2019]. International Journal of Pharmaceutical and Biological Archives 2012; 3(4): 893-896. www.ijpba.info

19. Shulka V, Tripathi RD ed. Charaka Samhita (ISBN: 978-817084-509-1) of Agnivesha. (Hindi). Vol-2. Reprint. Siddhi. Bastisiddhi 10/8. Chaukhambha Sanskrit Pratishthan. Delhi; 2013. p. 963.

20. Vipin Kumar. A Conceptual Study on Mode of Action of Nasya. [Cited on $12^{\text {th }}$ October 2019]. International Journal of Ayurveda and Pharma Research 2017; 5(7): 100-102.

21. Bartlett JA and Van Der Voort Maarschalk, K. Understanding the oral mucosal absorption and resulting clinical pharmacokinetics of asenapine. [Cited on $12^{\text {th }}$ October 29]. AAPS Pharm Sci Tech 2012; 13(4): 1110-1115. https://doi.org/10.1208/s12249-012-9839-7

22. Arun Raj GR, et al., Exploratory studies on the therapeutic effects of Kumarabharana Rasa in the management of chronic tonsillitis among children at a tertiary care hospital of Karnataka. [Cited on 12 $2^{\text {th }}$ October 2019]. Journal of Traditional and Complementary Medicine; 2014. http://dx.doi.org/10.1016/j.jtcme.2014.11.031

23. The Ayurvedic Pharmacopoeia of India (ISBN: 81-9011514-6) (Eng). Vol -1. $2^{\text {nd }}$ ed, 3:2, The controller of publications civil lines; 2003. p. 113.

24. Shailaja U, Rao PN, Girish KJ, Arun Raj GR. Clinical study on the efficacy of Rajayapana Basti and Baladi Yoga in motor disabilities of cerebral palsy in children. Ayu 2014; 35: 2949.

\section{Cite this article as:}

Shailaja U. and Mangala Jyothsna. Ayurvedic management of Spastic Cerebral Palsy: A Case Study. Int. J. Res. Ayurveda Pharm. 2020;11(2):1-4 http://dx.doi.org/10.7897/2277$\underline{4343.110219}$ every effort has been taken to verify the accuracy of the content published in our Journal. IJRAP cannot accept any responsibility or liability for the site content and articles published. The views expressed in articles by our contributing authors are not necessarily those of IJRAP editor or editorial board members. 